\title{
Heath species and heathlands of Italy: an analysis of their rela- tionships under the perspective of climate change based on the description of habitats used for the project "Carta della Natura" (Italian Map of Nature)
}

\author{
Enrico Feoli
}

Department of Life Sciences University of Trieste,

Via Weiss 2, 34100 Trieste Italy, e-mail: feoli@units.it

\begin{abstract}
The project "Italian Map of Nature" (IMN) is dedicated to create an electronic map (GIS) of the environmental state (quality and vulnerability) of the Italian territory at different scales. Up to now the GIS of IMN is offering maps at a scale 1:50,000. The environmental quality is estimated on the basis of biological description of habitats that can be mapped at this scale, the vulnerability on the basis of variables related to the anthropogenic pressure. In this paper I want to show that the information collected for creating the data base of habitats for mapping purposes may be useful for getting information related to the climatic niche width of the species considered habitat indicators. In this paper I consider the heath species characterizing the IMN habitats of Italy in order to get an indirect estimation of the climatic vulnerability of Italian heathlands. To measure the climatic niche width of the species I propose a formula that combines the number of habitats (they characterize) with the heterogeneity of the habitats according to their distribution in altitudinal belts and in biogeographic regions. The results offer parameters on which to base a discussion for policy conservation of heaths and heathlands in Italy under the perspective of climate change.
\end{abstract}

Key words: altitudinal belts, biogeographic regions, climate, data mining, habitats, information, nature conservation, niche, vulnerability.

\section{Introduction}

The convention of biodiversity conservation (CBC) suggests to address nature conservation towards a biosphere assessment that allows natural ecological processes such as evolutionary processes, including extinction and speciation to continue. The project of Italian Map of Nature (IMN) as described by Amadei et al. (2003, 2004), is working according to this suggestion by assuming that the role of protected areas (PAs) must be complemented by sound stewardship across the entire territory in which they have been established in order to avoid their "isolation" (see the report of Oilwatch \& World Rainforest Movement of 2004, Protected areas. Protected against whom?) (Anonymous 2004). IMN is thus producing maps of environmen- tal quality and vulnerability for all the Italian territory, at different scales, in line also with the concept of "Climate Change-integrated Conservation Strategies" introduced by Hannah et al. (2002). This concept is stressing that PAs management should be integrated with the "matrix" surrounding the PAs.

The IMN project, supported by a GIS technology, has created an open data base of the habitats of Italy that can be mapped at scale 1:50,000. Mapping at scale 1:250,000 and $1: 10,000$ are in progress (Amadei et al. 2003, 2004). The habitats are identified on the basis of CORINE (Anonymous 1991) and/or EUNIS (Davies \& Moss 2002) projects of the European Union (see Blasi \& Biondi 2009 for a recent handbook of Italian habitats). In the IMN project, the habitats are described by several biological characters (indicator species of flora and fauna, vegetation structure and 
syntaxonomy, endemism, etc.), by environmental characters related to soil, climate and by their geographical diffusion in Italy and outside Italy. Discussion about the choice of codes and the characters used for the habitat description in IMN is given by Amadei et al. (2004). In this paper I want to show that the information colleted for IMN could be useful for getting new information. In particular I want to show how it can be used to get a rough estimation of the climatic niche width of the species that could be useful for supporting policies of nature conservation. In this respect I agree with Huntley (2007) view: “...Strategies for the conservation of biodiversity in this world of rapid climatic change thus must focus upon the conservation of species, and of their inherent genetic variance, rather than upon the conservation of the communities or ecosystems that they form in any given region under present climatic conditions. Maintaining and, wherever possible, enlarging and augmenting, the existing network of protected areas will be a key part of any strategy for the conservation of biodiversity in a world of climatic change. Although many protected areas may experience substantial changes in the complement of species present, and in the communities and ecosystems that these species form, they nonetheless will provide vital nodes in an overall network that is necessary if species are to be able to attain their responses to climatic change..."

It looks obvious that under the pressure of climatic and land use changes a species with a wide niche has more probability to "survive" than a species with a narrow niche. In this paper I use the description of the habitats as it is done for mapping purposes in the project IMN (Angelini et al. 2009), with the aim to get rough measures of the climatic niche width of heath species characterizing the heathlands of Italy. The term heathlands indicates the habitats that are mainly of anthropogenic origin, dominated by heaths (Ericaceae) such as Calluna vulgaris (L.) Hull, spread in large areas of North-West and Central Europe on lowlands and hills, or dominated by species of the genera Rhododendron and Vaccinium on mountains (Angelini et al. 2009).

The anthropogenic heathlands had a very important role in the economy of human communities and they still characterize the cultural landscape of large areas with poor acidic soils and Altlantic climate, however they are suffering a decline owing to land abandonment and/or change in land use (see project HEATH: www.theheathproject.org. uk/news.html).

In Italy the extent of the anthropogenic heathlands on lowlands and hills was never so relevant as in other Northern countries of Europe (e.g. France, UK, Ireland, The Netherlands, Poland etc.), however in some parts of North Italy (Lombardy, Piedmont) it was big enough to impact the socio-cultural heritage (Giacomini \& Fenaroli 1958; Andreis \& Cerabolini 1995; Angiolini et al. 2007).

\section{Source of Data: Habitats characterized by heath species of the IMN project}

The handbook of habitats of IMN (Angelini et al. 2009) presents the list of habitats that can be mapped at scale 1:50,000 with the following information:

- the Corine code and the name of the habitat,

- the EUNIS code and the code of the Habitat Directive when available (DH),

- the main syntaxon or syntaxa to which the vegetation types of the habitat are belonging according to the Braun Banquet approach (Mueller Dombois \& Ellenberg 1974; Maarel 1975),

- a short description of the environment,

- Corine code of subtypes of habitats included in the one that can be mapped,

- indicator species ("guide" species). These may be just "indicator" or may correspond to the following categories: dominant species, with cover until 50\%; codominant with cover less than $50 \%$, but almost always present in the plant communities of the habitat; differential, i.e. capable to differentiate one habitat from at least another one; characteristic, namely the species present only in a vegetation type,

- biogeographical region: Alpine, Continental, Mediterranean,

- a rough indication of altitudinal belts (intervals in meters above sea level): coastal belt (0-50), lowland belt (0-350), hill belt (350-650), montane belt (650-1300), sub-Alpine belt (1300-1900), Alpine belt (1900-2400), top Alpine belt (over 2400),

- diffusion in Italy: North Italy, South Italy, Central Italy, North-West Italy etc. and Italian islands.

The list of the 32 habitats for which heath species are considered indicators is given in the Appendix. For each habitat I report only the information that is consistent in all the habitats, namely the Corine code, Eunis and DH code (Directive of Habitats 92/43EEC when present), the syntaxonomy of the plant communities, indicator species, altitudinal belt, biogeographic regions and diffusion in Italy.

\section{Data and Methods}

With the information of the IMN project (see Appendix) I constructed a binary data matrix $\mathbf{X}$ in which each habitat shows its belonging (1) to the sets defined by heath indicator species (species characterizing the habitats), to the sets defined by the altitudinal belts and to the sets defined by the biogeographic regions ( 0 indicate lack of belonging). I subdivided $\mathbf{X}$ into two sub-matrices: the matrix species habitats, $\mathbf{S}(21,32)$ and the matrix altitudinal belts $(6)$ and biogeographical regions (3)- habitats, $\mathbf{E}(9,32)$. 
Among the many possible ways to calculate the niche width (Pielou 1972; Hill 1973; Routledge 1979; Ludwig \& Reynolds 1988). I used the following formula:

$$
\mathrm{W}_{\mathrm{i}}=\mathrm{n}_{\mathrm{i}}{ }_{\mathrm{Hi}}
$$

where $n_{i}$ is the number of habitats belonging to the set defined by the i-th species,

$$
\mathrm{H}_{\mathrm{i}}=\left(\mathrm{c}_{\mathrm{i}} / \mathrm{n}_{\mathrm{i}} \mathrm{E}\right) \mathrm{D}_{\mathrm{i}}
$$

where $c_{i}$ is the number of environmental classes occupied by $n_{i}$ habitats characterized by the $i$-th species, $E$ is the total number of considered environmental classes. In this case $E=9$ ( 6 altitudinal belts and 3 biogeographical regions). $D_{i}$ is the average dissimilarity between the $n_{i}$ habitats calculated considering their belonging to the E environmental classes. To obtain $\mathrm{D}_{\mathrm{i}}$ I used the complement of Jaccard's index, that is the ratio between the intersection and the union of two sets (Podani 1994, 2000). The maximum value of $\left(c_{i} / n_{i} E\right)$ is 1 , when all the $n_{i}$ habitats belong to all the environmental classes, the minimum value it is $\mathrm{K} / \mathrm{E}$, with $\mathrm{K}$ equal to the number of types of environmental classes (in this case 2, namely the class of altitudinal belts and the class of biogeographical regions). $\mathrm{D}_{\mathrm{i}}$ is ranging between 0 and 1 , with 0 when the $n$ habitats are belonging to the same combination of environmental classes and 1 when they are all belonging to different combinations. It follows that $\mathrm{H}_{\mathrm{i}}$ is ranging between 0 and 1 . It actually is a factor correcting $n_{i}$. In fact if the $n_{i}$ habitats would be completely different in their belonging to environmental classes, a relative measure of the niche width of an indicator species is just $n_{i}$, it is is equal to 1 when all the $n_{i}$ habitats are equals in terms of their belonging to the E classes. $\mathrm{W}_{\mathrm{i}}$ is analogous to the number 1 of the Hill's series (Hill 1973).

With the $\mathrm{W}_{\mathrm{i}}$ values I calculated the relative vulnerability (or the risk of threat) of the species with the formula:

$$
\mathrm{V}_{\mathrm{i}}=1-\left(\mathrm{W}_{\mathrm{i}}-\mathrm{Wmin}\right) /(\mathrm{Wmax}-\mathrm{Wmin})
$$

In this case the relative vulnerability is maximum for a value equal to 1 and minimum for a value equal to 0 . The relative vulnerability of the habitats are calculated by averaging the vulnerability of the indicator species:

$$
\mathrm{V}_{\text {(ha) } \mathrm{j}}=1 / \mathrm{s} \Sigma_{\mathrm{i}} \mathrm{V}_{\mathrm{i}} \text { with } \mathrm{i}=1, . ., \mathrm{s}
$$

where $s$ is the number of indicator species of the $\mathrm{j}$-th habitat (ha).

The assumptions on which the above formulas are based are the following:

1 - The width of the climatic niche of an indicator species should be proportional to the number of different habitats that it characterizes and to the heterogeneity of such habitats $(\mathrm{H})$ in terms of climatic variables. I want to stress that to "characterize" one habitat is different from "being present" in that habitat, to characterize a habitat means to have a significant ecological role in that habitat or, at least, to have a high probability to be found only there.

2 - The altitudinal belts and the bio-geographic regions are environmental classes that represent respectively micro and macro climatic situations.

3 - The climatic vulnerability of a species should be inversely proportional to the width of its climatic niche, it follows that the climatic vulnerability of the habitats should be proportional to the vulnerability of their indicator species.

4 - The cartographic scale of 1: 50,000 of IMN defines a framework of reference, an ontology, that is based on a set of roles that makes possible to map the habitats at the same scale. In this framework the habitats are supposed to be equivalent at least with respect the spatial scale and therefore in terms of their inherent environmental spatial heterogeneity. This equivalence makes comparable the species niche widths.

All the computations and data management were done with the program MATEDIT (Burba et al. 2008).

\section{Results}

Table 1 shows for each of the heath indicator species: the total number of habitats characterized by the indicator species combinations (Tha), the ratio between the number of heathlands and Tha (THe/Tha), the vulnerability index $\left(\mathrm{V}_{\mathrm{i}}\right)$ calculated with formula 3 , the niche width (W) calculated with formula 1 , the relative vulnerability $(\mathrm{V}(\mathrm{ha}) \mathrm{j})$ of habitats calculated with formula 4 , and the minimal and maximal vulnerability given respectively by the $\mathrm{V}_{\mathrm{i}}$ of the least and the most vulnerable species of each habitat. The habitats in Table 1 are ordered according to a gradient of altitude, from the highest to the lowest one. 
Table 1. Distribution of the heath species characterizing 32 Habitats of the Italian Map of Nature (IMN) in the 5 habitats considered heathlands (17, 3, 4, 5, 2 for the name see the Appendix). For each species it is indicated: Tha $=$ number of habitats characterized by the single species, $\mathrm{THe} / \mathrm{Tha}=$ ratio between the number of heathlands $(\mathrm{THe})$ and $\mathrm{Tha}, \mathrm{V}_{\mathrm{i}}=$ vulnerability index calculated with formula 3, the niche width (W) calculated with formula 1 , and $\mathrm{V}_{\text {(ha)j }}=$ the relative vulnerability of habitats calculated with formula 3 , and the minimal and maximal vulnerability given respectively by the $V_{i}$ of the least and the most vulnerable species in each habitat

\begin{tabular}{|c|c|c|c|c|c|c|c|c|c|}
\hline Species & Tha & THe/Tha & $\mathrm{Vi}$ & Wi & 17 & 3 & 4 & 5 & 2 \\
\hline Moneses uniflora & 1 & 1 & 1 & 1 & 1 & 0 & 0 & 0 & 0 \\
\hline Rhodothamnus chamaecistus & 2 & 0.5 & 0.88 & 1.03 & 0 & 0 & 1 & 0 & 0 \\
\hline Arctostaphylos alpinus & 2 & 0.5 & 0.77 & 1.06 & 0 & 1 & 0 & 0 & 0 \\
\hline Kalmia procumbens & 2 & 1 & 0.77 & 1.06 & 0 & 1 & 1 & 0 & 0 \\
\hline Vaccinium gaultherioides & 3 & 0.66 & 0.54 & 1.12 & 0 & 1 & 0 & 1 & 0 \\
\hline Rhododendron hirsutum & 4 & 0.25 & 0.5 & 1.13 & 0 & 1 & 0 & 0 & 0 \\
\hline Calluna vulgaris & 4 & 0.25 & 0.42 & 1.15 & 0 & 0 & 0 & 0 & 1 \\
\hline Vaccinium vitis-idaea & 5 & 0.2 & 0.42 & 1.15 & 1 & 0 & 0 & 0 & 0 \\
\hline Arctostaphylos uva-ursi & 6 & 0.33 & 0.23 & 1.2 & 1 & 1 & 0 & 0 & 0 \\
\hline Erica carnea subsp. carnea & 8 & 0.25 & 0.19 & 1.21 & 1 & 1 & 0 & 0 & 0 \\
\hline Rhododendron ferrugineum & 8 & 0.25 & 0.19 & 1.21 & 1 & 1 & 0 & 0 & 0 \\
\hline Vaccinium myrtillus & 10 & 0.3 & 0 & 1.26 & 1 & 1 & 0 & 1 & 0 \\
\hline Arbutus unedo & 3 & & 0.65 & 1.09 & 0 & 0 & 0 & 0 & 0 \\
\hline Erica arborea & 5 & & 0.62 & 1.1 & 0 & 0 & 0 & 0 & 0 \\
\hline Erica cinerea & 1 & & 1 & 1 & 0 & 0 & 0 & 0 & 0 \\
\hline Erica forskalii & 1 & & 1 & 1 & 0 & 0 & 0 & 0 & 0 \\
\hline Erica multiflora & 3 & & 0.62 & 1.1 & 0 & 0 & 0 & 0 & 0 \\
\hline Orthilia secunda & 1 & & 1 & 1 & 0 & 0 & 0 & 0 & 0 \\
\hline Pyrola rotundifolia & 1 & & 1 & 1 & 0 & 0 & 0 & 0 & 0 \\
\hline Vaccinium microcarpum & 1 & & 1 & 1 & 0 & 0 & 0 & 0 & 0 \\
\hline Vaccinium uliginosum & 2 & & 0.81 & 1.05 & 0 & 0 & 0 & 0 & 0 \\
\hline $\mathrm{V}(\mathrm{ha}) \mathrm{j}$ & & & & & 0.3 & 0.4 & 0.82 & 0.27 & 0.42 \\
\hline $\mathrm{V}(\mathrm{ha}) \min$ & & & & & 0 & 0 & 0.77 & 0 & 0.42 \\
\hline V(ha)max & & & & & 1 & 0.77 & 0.88 & 0.54 & 0.42 \\
\hline \multicolumn{10}{|l|}{ Altitudinal belts } \\
\hline Alpine & & & & & 1 & 1 & 0 & 0 & 0 \\
\hline Sub-Alpine & & & & & 0 & 1 & 1 & 0 & 0 \\
\hline Montane & & & & & 0 & 1 & 1 & 1 & 1 \\
\hline Hill & & & & & 0 & 0 & 0 & 0 & 1 \\
\hline Lowlands & & & & & 0 & 0 & 0 & 0 & 1 \\
\hline Coastal zones & & & & & 0 & 0 & 0 & 0 & 0 \\
\hline \multicolumn{10}{|l|}{ Biogeographic region } \\
\hline Alpine & & & & & 1 & 1 & 1 & 0 & 1 \\
\hline Continental & & & & & 0 & 1 & 1 & 1 & 1 \\
\hline Mediterranean & & & & & 0 & 0 & 1 & 1 & 0 \\
\hline
\end{tabular}




\section{Discussion}

The Italian Flora of Pignatti (1982) and the recent check list of Conti et al. (2005) indicate for Italy 33 heath species. Of these, according to Angelini et al. (2009), 21 are considered habitat indicators. Different combinations of these 21 species characterize 32 different types of habitats that are mapped at scale 1:50,000 of IMN. Only 5 of these habitats are considered heathlands by Angelini et al. (2009). They are presented in Table 1 (see Appendix for the code) arranged following a decreasing gradient of elevation, from Alpine belt to lowlands. According to IMN (Angelini et al. 2009), the habitats characterized by heaths located in the altitudinal belt corresponding to "coastal zone" (0-50 m.a.s.1) of Italy are not considered heathlands, but Mediterranean shrublands. Only 12 species out of the 21 give species combinations characterizing the five heathlands. The number of heaths species is higher in the habitats belonging to Alpine and sub-Alpine altitudinal belts (habitats 17 and 3 with respectively 6 and 8 heath species) while it is low ( 2 and 1 species) in the habitats belonging to lower altitudinal belts.

The vulnerability of the types of heathlands $\left(\mathrm{V}_{(\mathrm{Ha}))}\right.$ calculated with formula 4 shows that the most vulnerable heatlands are those characterized by the joint presence of Kalmia procumbens and Rhodothamnus chamaecistus (Habitat number 4), namely those corresponding to the extreme habitat on mountain and sub-Alpine windy edges. The least vulnerable is the one characterized by the joint presence of Vaccinium myrtillus and Vaccinium gaultherioides (Habitat number 5) distributed in Continental and Mediterranean biogeographic regions and Montane altitudinal belt. The next vulnerable habitat, that however does not reach the 0.50 value of $\left(\mathrm{V}_{(\mathrm{Ha})}\right)$, is number 2 , characterized by Calluna vulgaris. This is the habitat distributed on montane, hill and lowland altitudinal belts and in Alpine and continental biogeographic regions that corresponds to the heathland widespread in North and Central Europe. The habitats of the Alpine and sub-Alpine altitudinal belts and in Alpine and Continental biogeographic regions (Habitats number 17 and 3) have a relative low average vulnerability, however they contain the species with the highest vulnerability, respectively Moneses uniflora and Arctostaphylos alpinus.

The ratio (THe/Tha) indicates that actually only few species of the 12 species characterize exclusively heathlands, the majority of the species characterize also other habitats, mainly forests and woodlands (see Appendix). This parameter reinforces the idea that the conservation of heathlands is to be considered within the process of vegetation dynamics related to secondary and primary forests. The heathlands will have the possibility to survive in a process of climatic changes only if the habitats of pro- tected areas are connected in a way to ensure the necessary plant dispersal and the related gene flow. In this respect I like to conclude this paper quoting again the views of Huntley (2007):... "Key challenges will include that of ensuring that the designation of sites as protected areas can be maintained, even when the original legal basis upon which their current designation rests may no longer exist because of inevitable changes in species' distributions and in the character of the ecosystems present. It also may often be the case that the management of a protected area required, on the one hand, to maintain maximal populations of rare or threatened species present therein so as to maximise their potential to achieve dispersal and range adjustment in response to climatic change, and on the other hand, to facilitate colonisation by dispersing propagules or offspring of species for which the area has become newly suitable as a consequence of climatic change, may conflict. In itself this is a strong argument for the substantial enlargement of existing protected areas, where this is possible, or for the addition of complementary areas to the network where enlargement of existing areas is not possible...".

\section{Conclusion}

In this paper I present the results of an exercise of data mining to show how information stored in data bases and/ or published in papers or books as "coded knowledge" can be useful to get new data for generating new information that can be useful for new purposes. For this exercise I used the information collected in the data bases of the project of Italian Map of Nature at scale 1:50,000, that constitutes a framework consistent with at least one spatial property of the habitats, namely their extent. I have chosen to use the "coded knowledge" of IMN at this scale to get some objective information about the vulnerability of the heath species and the habitats they characterize with respect to climate changes. The results offer parameters on which to base discussions for developing policy conservation strategies keeping in mind that the scale 1:50,000 defines habitat types at one hierarchical level that allows to map them at a "reasonable" extension. We can suppose that if one habitat can be mapped at scale 1:50,000 and it is represented by several polygons, its extent should be enough to guarantee its survival in case of gradual climatic changes and "reasonable" anthropogenic pressure, provided the habitats have the necessary connections to guarantee the migration of the species and their gene flow. The key point of future research is therefore to combine parameters of climatic vulnerability of species with parameters of connectivity between habitats, within and outside the protected areas. 


\section{References}

Amadei M., Bagnaia R., Laureti L., Lugeri F., Lugeri N., Feoli E., Dragan M., Fernetti M. \& Oriolo G., 2003, Il progetto carta della natura alla scala 1:250,000, Metodologia di realizzazione, Manuali e Linee Guida APAT $17 / 2003$

Amadei M., Bagnaia R., Laureti L., Lugeri F., Lugeri N., Feoli E., Dragan M., Fernetti M., Oriolo G., Ferrarini A., Rossi O. \& Rossi P., 2004, Il Progetto Carta della Natura alla scala 1:50,000, Metodologia di realizzazione, Manuali e Linee Guida APAT 30/2004.

Andreis C. \& Cerabolini B., 1995, La brughiera briantea: la vegetazione ed il Piano di gestione, Coll. Phytosoc. 21: $195-224$

Angelini P., Bianco P., Cardillo A., Francescato C. \& Oriolo G., 2009, Gli Habitat in carta della Natura, Schede descrittive degli habitat per la cartografia alla scala 1:50,000, ISPRA 49/2009.

Angiolini C., Foggi B., Viciani D. \& Gabellini A., 2007, Acidophytic shrubland in the north-west of the Italian peninsula: Ecology, chorology and syntaxonomy, Plant Biosystems 141(2): 134-163.

Anonymous, 1991, CORINE Biotopes manual, Habitats of the European Community (Vol.2) EUR 12587/3, Office for Official Publications of the European Communities, Luxembourg: Commission of the European Communities.

Anonymous, 2004, Protected areas. Protected against whom? Oilwatch \& World Rainforest Movement.

Blasi C. \& Biondi E., 2009, Manuale Italiano di interpretazione degli habitat della direttiva 92/43/CEE", Ministero dell'Ambiente e della Tutela del territorio e del Mare http://vnr.unipg.it/habitat/index.jsp.

Burba N., Feoli E. \& Malaroda M., 2008, MATEDIT: a software tool to integrate information in decision making processes, [in:] R. Neves, JW. Baretta \& M. Mateus (eds.) Perspectives on Integated Coastal Zone Management in South America, IST PRESS, Lisboa: $123-127$.

Conti F., Abbate G., Alessandrini A. \& Blasi C. (eds.), 2005, An annotated checklist of the Italian vascular flora, Palombi Editori, Roma.

Davies C.E. \& Moss D., 2002, EUNIS Habitat Classification. Final Report to the European Topic Centre on Nature Protection and Biodiversity, European Environmental Agency, February 2002.

Giacomini V. \& Fenaroli L., 1958, La Flora. Conosci l'Italia Vol. II, Touring Club Italiano, Milano.

Hannah L., Midgley G.F. \& Millar D., 2002, Climate change-integrated conservation strategies, Global Ecology and Biogeography 11: 485-495.
Hill M.O., 1973, Diversity and evenness: a unyfing notation and its consequences, Ecology 54: 427-432.

Huntley B., 2007, Climatic change and the conservation of European biodiversity: towards the development of adaptation strategies, A discussion paper prepared for the 27th meeting of the Standing Committee, Convention on the Conservation of European Wildlife and Natural Habitats, Strasbourg, 26-29 November 2007, Council of Europe.

Ludwig J.A. \& Reynolds J.F., 1988, Statistical ecology a primer on methods and computing, J. Wiley \& Sons, New York.

Maarel E. van der, 1975, The Braun-Blanquet approach in perspective, Vegetatio 30: 213-219.

Mueller-Dombois D. \& Ellenberg H., 1974, Aims and methods of vegetation ecology, J. Wiley \& Sons, New York.

Pielou E.C., 1972, Niche Width and Niche Overlap: A Method for Measuring Them, Ecology 53(4): 687-692.

Pignatti S., 1982, Flora d'Italia, Edagricole, Bologna.

Podani J.,1994, Multivariate Data Analysis in Ecology and Systematics. A Methodological Guide to the SYN-TAX 5.0 package, SPB Academic Publishing bv, The Hague.

Podani J., 2000, Introduction to the Exploration of Multivariate Biological Data, Backhuys Publishers, Leiden.

Routledge R.D., 1979, Niche metrics and diversity components, Oecologia 43: 121-124.

\section{Appendix}

The following is the list of the 32 habitats for which heath species are within the indicator group of species

(Angelini et al. 2009). Each habitat is coded with a number from 1 to 32 and the Corine code. For each habitat I indicated also Eunis and DH code (Directive of Habitats 92/43EEC when present), the Syntaxonomy of the plant communities, Indicator species, Altitudinal belt, Biogeographic region and Diffusion in Italy:

\section{1) 16.28 Shrublands on dunes}

EUNIS=B1.64 DH=2260

Syntaxonomy: Quercion ilicis, Pistacio-Rhamnetalia

Indicator species: Arbutus unedo, Artemisia arborescens, Cistus sp. pl., Clematis cirrhosa, Erica multiflora, Halimium halimifolii, Osyris alba, Phillyrea angustifolia, Phillyrea latifolia, Pistacia lentiscus, Prasium majus, Rhamnus alaternus, Rosmarinus officinalis, Teucrium fruticans, Teucrium flavum

Biogeographic regions: Mediterranean

Altitudinal belts: Coastal

Diffusion: Italy and Islands 
2) 31.22 and 31.21 Sub-Altlantic heathlands with Calluna and Vaccinium sp.pl.

EUNIS=F4.2 DH=4030

Syntaxonomy: Genistion pilosae

Indicator species: Genista anglica, Genista germanica, Genista pilosa (character species), Calluna vulgaris, Chamaecytisus hirsutus, Tuberaria lignosa, Empetrum nigrum

Biogeographic regions: Alpine, Continental

Altitudinal belts: Lowland, Hills, Montane

Diffusion: North and Central Italy

3) 31.42 31.41, 31.44, 31.47, 31.48 and 31.49: Sub-Alpine heathlands with Rhododendron and Vaccinium sp.pl.

EUNIS=F2.2 DH=4060

Syntaxonomy: Rhododendro-Vaccinion, Ericion carneae Indicator species:Arctostaphylos uva-ursi, Arctostaphylos alpina, Astrantia minor, Dryas octopetala, Empetrum hermaphroditum, Erica carnea, Genista radiata, Helianthemum alpestre, Loiseleuria procumbens, Rhododendron ferrugineum, Rhododendron hirsutum, Vaccinium gaultherioides, Vaccinium myrtillus

Altitudinal belts: Montane, Sub-Alpine, Alpine

Biogeographic regions: Continental, Alpine

Diffusion: North Italy

4) 31.43: Heathlands with dwarf Juniperus sp. pl. EUNIS=F2.2 DH=4060

Syntaxonomy: Juniperion nanae, Daphno oleoidis-Juniperion alpinae, Pino-Juniperetalia

Indicator species: Juniperus communis var. alpina, Juniperus sabina (Alps), Juniperus communis var. hemisphaerica (Apennines and Sicily) (dominants), Loiseleuria procumbens, Cetraria nivalis, Huperzia selago, Hylocomium splendens, Rhythidiadelphus triquetrus (Alps), Daphne oleoides, Helianthemum grandiflorum, Rhodothamnus chamaecistus, Hypericum richeri

Altitudinal belts: Montane, Sub-Alpine

Biogeographical regions: Alpine, Continental, Mediterranean

Diffusion: North Italy, Central Italy

5) 31.4 A: Heathlands with Vaccinium sp.pl. of the Apennines

EUNIS=F2.2, DH=4060

Syntaxonomy:Empetro-Vaccinietum gaultherioides, Vaccinio-Hypericetum richeri

Indicator species: Empetrum hermaphroditum, Hypericum richeri, Vaccinium myrtillus, Vaccinium gaultherioides.

Biogeographic regions: Continental, Mediterranean

Altitudinal belts: Montane

Diffusion:North Italy and Central Italy
6) 31.51 and 3.52 Plant communities dominated by Pinus mugo of Central- Eastern Alps

EUNIS=F2.4 DH=4070

Syntaxonomy: Erico-Pinion mugo, Rhododendro-Vaccinion

Indicator species: Pinus mugo (dominant), Erica carnea, Rhododendron ferrugineum, Rhodothamnus chamaecistus, Sorbus chamaemespilus (co-dominant), Rhododendron hirsutum, Valeriana tripteris, Valeriana austriaca (differentials with respect to $\mathbf{3 1 . 5 3}$ )

Biogeographic regions: Continental, Alpine

Altitudinal belts: Montane, Sub-Alpine

Diffusion: North Italy (from Eastern to Central Alps)

7) 31.53 Plant communities dominated by Pinus mugo of Western Alps

EUNIS=F2.4 DH=4070

Syntaxonomy: Arctostaphylo-Pinetum mughi

Indicator species: Pinus mugo (dominant), Arctostaphylos uva-ursi, Helianthemum oelandicum subsp. italicum, Pinus uncinata (differential with respect to 31.52)

Biogeographic regions: Alpine

Altitudinal belts: Montane, Sub-Alpine, Alpine

Diffusion: North Italy (Western Alps)

8) 32.212 Shrublands with Erica multiflora and Erica forskalii

EUNIS=F5.5

Syntaxonomy: Rosmarino-Ericion multiflorae

Indicator species: Erica multiflora, E. forskalii (dominants), Cistus creticus, Myrtus communis, Phillyrea angustifolia, Rosmarinus offinalis (co-dominant), Teucrium polium

Biogeographic regions: Mediterranean

Altitudinal belts: Coastal, Lowland, Hill

Diffusion: Central and South Italy

9) 32.4 Mediterranean Shrublands

EUNIS=F6.1

Syntassonomy: Rosmarino-Ericion multiflorae

Indicator species: Cistus albidus, Cistus creticus subsp. eriocephalus, Cistus clusii, Dorycnium pentaphyllum, Erica multiflora, Fumana ericoides subsp. ericoides, Fumana thymifolia, Globularia alypum, Helianthemum caput-felis, Micromeria microphylla, Osyris alba, Rosmarinus officinalis, Santolina etrusca, Teucrium polium, Thymelaea hirsuta, Thymus sp.pl.

Biogeographic regions: Mediterranean Altitudinal belts: Coastal, Lowland, Hill Diffusion: Central and South Italy, Islands

10) 41.11 Central European Beech-woods on acidic soils

EUNIS $=\mathrm{G} 1.6 \mathrm{DH}=9110$ 
Syntaxonomy: Luzulo-Fagion

Indicator species: Fagus sylvatica (dominant), Picea abies, Vaccinium myrtillus, Rhododendron ferrugineum (co-dominants), Dryopteris carthusiana, Luzula nivea (characteristics), Athyrium filix-femina, Calamagrostis arundinacea, Deschampsia caespitosa, Gymnocarpium dryopteris, Luzula albida, Luzula luzuloides, Luzula nivea, Luzula sylvatica, Veronica urticifolia, Acer pseudoplatanus, Betula pendula, Polygonatum verticillatum, Quercus petraea Biogeographic regions: Continental

Altitudinal belts: Montane

Diffusion: North Italy

11) 41.171 Forests with Fagus sylvatica on acidic and neutral soils

EUNIS=G1.6

Syntaxonomy: Staphyleo pinnatae-Fagetum sylvaticae Indicator species: Fagus sylvatica (dominant), Centaurea montana, Hieracium murorum, Staphylea pinnata (characteristic), Anemone nemorosa, Asarum europaeum, Avenella flexuosa, Dryopteris filix-mas, Epilobium montanum, Luzula nivea, Luzula luzuloides, Luzula pedemontana, Luzula sylvatica, Majanthemum bifolium, Oxalis acetosella, Polystichum aculeatum, Vaccinium myrtyllus, Veronica officinalis (differential with respect to 41.175), Crataegus laevigata, Carpinus betulus, Euonymus latifolius

Biogeographic regions: Continental

Altitudinal belts: Montane

Diffusion: North and Central Italy

\section{2) 41.59 Forests of Quercus petraea of North Italy} EUNIS $=\mathrm{G} 1.8$

Syntaxonomy: Ostryo-Carpinion p.p., Quercion pubescentis-petreae

Indicator species: Quercus petraea (dominant), Quercus robur, Quercus pubescens (codominant), Erica cinerea, Physospermun cornubiense, Phyteuma betonicifolium, Potentilla alba, Teucrium scorodonia (characteristics), Festuca heterophylla, Pteridium aquilinum, Vaccinium myrtillus

Biogeographic regions: Continental

Altitudinal belts: Hill, Montane

Diffusion: North Italy

13) 41.7512 South- Italian Woodlands with Quercus cerris and Quercus frainetto

EUNIS $=$ G1.7 DH=9280

Syntaxonomy: Teucrio siculi-Quercion cerridis, PinoQuercion congestae

Indicator species: Quercus frainetto (dominant), Acer campestre, Carpinus orientalis, Fraxinus ornus, Quercus cerris (codominant), Echinops siculus, Malus florentina, Serratula tinctoria (characteristics), Erica arborea, Crataegus monogyna, Cytisus villosus, Luzula forsteri, Pyrus pyraster, Rosa sempervirens, Tecurium siculum, Viola alba, Ruscus aculeatus, Stachys officinalis

Biogeographic regions: Mediterranean

Altitudinal belts: Lowland, Hill

Diffusion: Central-South Italy

14) 42.13 Forests with Abies alba on acidic soils of Alps and Apennines

EUNIS=G3.1

Syntaxonomy: Abieti-Fagetum s.1., Rhododendro-Abietetum

Indicator species: Abies alba (dominant), Larix decidua, Fagus sylvatica, Pinus sylvestris (co-dominant), Anemone trifolia, Huperzia selago, Melampyrum sylvaticum, Pyrola rotundifolia, Rhododendron ferrugineum (Alps), Acer pseudoplatanus, Acer opalus subsp. obtusatum, Carpinus betulus, Cardamine chelidonia (Apennines), Calamagrostis villosa, Homogyne alpina, Luzula nivea, Oxalis acetosella, Polygonatum verticillatum, Vaccinium myrtillus, Veronica urticifolia

Biogeographic regions: Continental

Altitudinal belts: Montane

Diffusion: North and Central Italy

15) 42.21 Sub-Alpine forests with Picea abies EUNIS=G3.1 DH=9410

Syntaxonomy: Larici-Piceetum, Adenostylo glabrae-Piceetum, Asplenio-Piceetum, Homogyno-Piceetum

Indicator species: Picea abies (dominant), Abies alba, Larix decidua, Pinus cembra (co-dominant), Adenostyles glabrae, Arnica montana, Campanula barbata, Nardus stricta, Pinus mugo, Rhododendron ferrugineum (differentials), Avenella flexuosa, Daphne mezereum, Homogyne alpina, Laburnum alpinum, Oxalis acetosella, Sorbus aria, Vaccinium myrtillus, Vaccinium vitis-idaea

Biogegraphic regions: Alpine, Continental Altitudinal belts: Sub-Alpine Diffusion: North Italy

16) 42.242 Forests of Picea abies of Apennines

EUNIS $=\mathrm{G} 3.1 \mathrm{DH}=9410$

Syntaxonomy: Vaccinio-Piceetea

Indicator species: Picea abies (dominant), Abies alba, Fagus sylvatica (co-dominants), Luzula sieberi, Orthilia secunda, Vaccinium gaultherioides

Biogeographic regions: Continental

Altitudinal belts: Montane

Diffusion: West-North Italy, Central Italy

17) 42.31/2 to 9 Woodlands (and heathlands) with Pinus cembra and Larix decidua on acidic soils

EUNIS=G3.2 DH=9420

Syntaxonomy: Larici-Pinetum cembrae (Piceion excelsae) 
Indicator species: Pinus cembra, Larix decidua (dominants), Arctostaphylos uva-ursi, Calamagrostis villosa, Erica carnea, Picea abies, Rhododendron ferrugineum, Vaccinium myrtillus, Vaccinium vitis-idaea (co-dominant), Linnaea borealis, Listera cordata, Luzula luzulina, Moneses uniflora (characteristics), Alnus viridis, Luzula albida Biogeographic region: Alpine

Altitudinal belts: Sub-Alpine, Alpine

Diffusion: North Italy

18) 42.321 Woodlands of Pinus cembra and Larix decidua on basic soils

EUNIS=G3.2 DH=9420

Syntaxonomy: Pinetum cembrae (Erico-Pinion mugo) Indicator species: Larix decidua, Pinus cembra (dominants), Alnus viridis, Erica carnea, Pinus mugo, Polygala chamaebuxus, Rhododendron hirsutum (co-dominants)

Biogeographic regions:Alpine

Altitudinal belts: Sub-Alpine

Diffusion: North-East Italy

19) 42.331 Forests of Larix decidua and Pinus uncinata

EUNIS=G3.1 DH=9430

Syntaxonomy: Vaccinio-Piceion

Indicator species: Larix decidua, Pinus uncinata (dominants) Pinus cembra, Rhododendron ferrugineum, Vaccinium myrtillus, Vaccinium vitis-idaea, Vaccinium uliginosum

Biogeographic regions: Alpine, Continental

Altitudinal belts: Montane, Sub-Alpine

Diffusion: North-West Italy

\section{0) 42.332 Forests of Pinus cembra}

EUNIS $=$ G3 2 DH=9420

Syntaxonomy: Vaccinio-Piceion

Indicator species: Pinus cembra (dominant), Arctostaphylos uva-ursi, Pinus sylvestris, Pinus uncinata, Juniperus communis var. alpina (codominants)

Biogeographic regions: Alpine

Altitudinal belts: Montane, Sub-Alpine

Diffusion: North-West Italy

21) 42.41 Forests of Pinus uncinata on acidic soils EUNIS $=\mathrm{G} 3.3 \mathrm{DH}=9430$

Syntaxonomy: Rhododendro-Pinetum uncinatae, Calamagrostio villosae-Pinetum unicinatae

Indicator species: Pinus uncinata (dominant), Rhododendron ferrugineum, Vaccinium uliginosum, Homogyne alpina (differential with respect to 42.42), Calluna vulgaris, Deschampsia flexuosa, Calamagrostis villosa, Vaccinium vitis-idea, Vaccinium myrtillus

Biogeographic regions: Alpine

Altitudinal belts: Sub-Alpine
Diffusion: North-West Italy

22) 42.42 Forests of Pinus uncinata on basic soils EUNIS $=$ G3.3 DH=9430

Syntaxonomy: Erico-Pinion

Indicator species: Pinus uncinata (dominant), Arctostaphylos uva-ursi, Arctostaphylos alpina, Amelanchier ovalis, Erica carnea, Juniperus communis var. alpina, Rhododendron hirsutum, Sesleria caerulea (differential with respect 42.41), Vaccinium vitis-idea

Biogeographic regions: Alpine, Continental

Altitudinal belts: Montane

Diffusion: North-West Italy

23) 42.52 Forests of Pinus sylvestris on acidic soils EUNIS $=$ G3.4

Syntaxonomy: Dicrano-Pinion (Vaccinio-Piceetea)

Indicator species: Pinus sylvestris (dominant), Quercus robur, Quercus petraea, Betula pendula, Fagus sylvatica (co-dominanti and differentials), Dicranum fuscescens, Dicranum undulatum (characteristics), Calluna vulgaris, Cladonia rangiferina, Cladonia arbuscula, Vaccinium myrtillus (differentials)

Biogeographic regions: Alpine, Continental

Altitudinal belts: Hill, Montane

Diffusion: North Italy

24) 42.54 Forests of Pinus sylvestris on neutral and basic soils

EUNIS $=$ G3.4

Syntaxonomy: Erico-Pinion sylvestris (Erico-Pinetea)

Indicator species: Pinus sylvestris (dominant), Erica carnea (co-dominant), Chamaecytisus purpureus, Epipactis atrorubens, Goodyera repens (characteristics), Carex alba, Carex ornithopoda, Pyrola chlorantha, Melampyrum pratense, Melampyrum sylvaticum (differential), Carex humilis, Calamagrostis varia, Polygala chamaebuxus, Sesleria caerulea

Biogeographic regions: Alpine, Continental

Altitudinal belts: Hill, Montane

Diffusion: North Italy (Alps and Pre-Alps)

25) 42.58 Mesophylous forests of Pinus sylvestris EUNIS $=$ G3.4

Syntaxonomy: Erico-Pinetum sylvestris

Indicator species: Pinus sylvestris (dominant), Arctostaphylos uva-ursi, Calluna vulgaris, Erica carnea, Polygala chamaebuxus, Neottia nidus-avis (differentials)

Biogeographic regions: Alpine, Continental

Altitudinal belts: Hill, Montane

Diffusion: North-West Italy

26) 42.611 Forests of Pinus nigra

EUNIS $=\mathrm{G} 3.5 \mathrm{DH}=9530$ 
Syntaxonomy: Erico-Fraxinion orni (Erico-Pinetea) Indicator species: Pinus nigra subsp. austriaca (dominant), Ostrya carpinifolia, Pinus sylvestris (co-dominants), Amelanchier ovalis, Calamagrostis varia, Chamaecytisus purpureus, Epipactis atrorubens, Erica carnea, Polygala chamaebuxus, Sesleria albicans

Biogeographic region: Alpine, Continental

Altitudinal belts: Montane

Diffusion: North-East Italy

27) 42.82 Forests of Pinus pinaster (=P. mesogeensis) EUNIS $=\mathrm{G} 3.7 \mathrm{DH}=9540$

Syntaxonomy: Quercion ilicis

Indicator species: Pinus pinaster (dominant), Erica arborea, Pistacia lentiscus (co-dominant)

Biogeographic regions: Mediterranean

Altitudinal belts: Coastal

Diffusion: West Italy, Islands

28) 45.21 Forests and woodlands of Quercus suber EUNIS=G2.1 DH=9330

Syntaxonomy: "Quercetum suberis"

Indicator species: Quercus suber (dominant), Quercus congesta (co-dominant in Sardinia), Calicotome spinosa, Cistus salvifolius, Crataegus monogyna, Cytisus villosus, Erica arborea, Genista aristata, Rubus ulmifolius (codominants), Eryngium bocconei (Sicily), Melica arrecta, Oenanthe pimpinelloides, Pulicaria odora, Stachys officinalis (characteristics), Asparagus acutifolius, Pyrus amygdaliformis, Quercus pubescens, Quercus frainetto

Biogeographic regions: Mediterranean

Altitudinal belts: Lowland, Hill

Diffusion: Central-South Italy, Islands

29) 45.31B, 45.319, 45.317 Forests and woodland with Quercus ilex and Arbutus unedo

EUNIS $=$ G2.4 DH=9340

Syntaxonomy: Erico arboreae-Quercetum ilicis, OrnoQuercetum ilicis, Prasio majoris-Quercetum ilicis, Pyro amygdaliformis-Quercetum ilicis

Indicator species: Quercus ilex (dominant), Erica arborea, Arbutus unedo, Fraxinus ornus, Ostrya carpinifolia, Quercus pubescens (co-dominants), Asplenium onopteris, Hedera helix, Juniperus communis, Phillyrea latifolia, Rosa sempervirens, Rubia peregrina, Rubus ulmifolius, Ruscus aculeatus, Prasium majus (characteristics), Arisarum vulgaris, Carex distachya, Clematis cirrhosa, Lonicera implexa, Pistacia lentiscus, Pyrus spinosa, Rhamnus alaternus, Rubia peregrina, Ruscus aculeatus, Tamus communis

Biogeographic regions: Mediterranean

Altitudinal belts: Costal zone, Lowland, Hill

Diffusion: Italy and Islands
30) 45.42 Woodlands with Quercus coccifera (thorny oak)

EUNIS $=$ G2.1

Syntaxonomy: Arbuto-Quercetum calliprini, Hedero helicis-Quercetum calliprini, Rusco-Quercetum calliprini, Chamaeropo-Quercetum calliprini

Indicator species: Quercus coccifera (dominante), Arbutus unedo, Calicotome villosa, Chamaerops humilis, Hedera helix, Juniperus oxycedrus subsp. macrocarpa, Prasium majus, Rhamnus alaternus, Rubia peregrinae, Teucrium fruticans

Biogeographic regions: Mediterranean

Altitudinal belts: Lowland, Hill

Diffusion: South Italy, Islands

31) 84.6 Pasturelands with sparse trees

EUNIS $-\mathrm{DH}=6310$

Syntaxonomy: Quercetea ilicis, Cisto-Lavanduleatea, Thero-Brachypodietea, Helianthemetea guttati

Indicator species: Quercus ilex, Quercus pubescens s.1., Quercus suber, Olea europaea, Ceratonia siliqua, Erica arborea, Cistus salvifolius

Biogeographic regions: Mediterranean

Altitudinal belts: Lowland, Hill

Diffusion: Italy

32) 51.1 Peat bogs

EUNIS=D1.1 DH=7110

Syntaxonomy: Oxycocco-Sphagnetea

Indicator species: Andromeda polifolia, Carex pauciflora, Drosera rotundifolia, Drosera anglica, Drosera intermedia, Eriophorum vaginatum, Polytrichum juniperinum, Sphagnum fuscum, Sphagnum imbricatum, Sphagnum magellanicum, Sphagnum compactum, Rhynchospora alba, Rhynchospora fusca, Scheuchzeria palustris, Utricularia intermedia, Utricularia minor, Utricularia ochroleuca, Vaccinium microcarpum

Biogeographic regions: Mediterranean, Continental, Alpine

Altitudinal belts: Hill, Montane

Diffusion: Italy 